\title{
Gondang Hasapi in Holding Ritual Parmalim Si Pahasada (Study of the Shapes of Gondang and its Functions)
}

\author{
Esra P.T Siburian \\ Universitas Negeri Medan \\ b4khrul.4m4l@gmail.com
}

\begin{abstract}
This paper aims to discuss the existence of a form of gondang at the ritual ceremony of Si Pahasada, and how its function at the ritual ceremony of Si Pahasada in Huta High of North Sumatra is the subject matter to be discussed. The method used in this study is by using descriptive qualitative method. Collecting data is done through observation, interview, documentation, and bibliography. In this study it is found that there are 12 dishes reportoar gondang kesumpaan presented during this ritual. In this study also found eight functions of gondang in the ritual of Parmalim Si Pahasada, namely: 1) Aesthetic function, 2) communication functions, 3) symbolic functions, 4) physical response function, 5) enforcing social norms, 5) validation of social institutions. 6) religious ritual function, 7) cultural continuity and stability, 8) contribution to community integration.
\end{abstract}

Keywords : Gondang Hasapi;Parmalim; Si Pahasada

\section{Introduction}

The Batak Toba people in North Sumatra know a belief called "Parmalim". Parmalim is a belief that follows the teachings ordered by the sayings they believe to bring blessings to their followers. Parmalim refers to Malim's believers. Malim's belief in Batak Toba is called Ugamo Malim. Malim's belief in fact is the original religion of Batak Toba, but there are influences of Christianity, Khatolik and also the influence of Islam that resulted in some Batak Toba people accept Christianity, Khatolik and Islam.

God in the Parmalim belief is called Debata Mula Jadi Na Bolon (God Almighty) as the creator of man, the heavens, the earth and the contents of the universe worshiped by the believers of Parmalim. Parmalim's beliefs were adopted by some Toba Batak tribes in North Sumatra Province, for Batak Toba people the belief in the existence of God called Debata Mulajadi Na Bolon has been planted for a long time. On the other hand, the life of the hobo people also implies a strong influence in their view of life which includes three aspects, namely: honor, hagabeon (many offspring) and hamoraon (wealth). For Batak people forbeing honored and glorified by others in the spirit world of those who have died, so it is necessary to have a good descendant of both men and women and spread in the village of eighty (eight winds).

In North Sumatra, precisely in Toba Samosir District still have a group of people who firmly and still adhere to the religion of their ancestors ie Parmalim religion. But since ancient times there was the largest Parmalim group, Malim group based in Huta Tinggi, Laguboti District, Toba Samosir District. Parmalim's main feast is called Si Pahasada (ie the First month) which is a memorial of the Lord's birthday Mulajadi Na Bolon, Raja Si Marimbulubosi (King of Full Affliction), as well as a symbol of victory for the Parmalim people in gaining faith. This Si Pahasada festival is usually performed in Paleally Bale Partonggoan (home of worship) in Hutatinggi village. This ritual is held when entering Batak's new year, February-March, and Si Pahalima (ie the Fifth month), which means Pameleon Bolon (Harvest Festival) held between June-July. This ritual is performed once a year and is the most lively and celebrated ceremony in the center of Parmalim in Huta Tinggi. This ceremony is done to be grateful for the harvest they earn. The ceremony is also an effort 
to raise social funds along with setting aside some of the harvest for the needs of the needy citizens.

The form of presenting Parmalim Sipaha Sada ritual ceremonies is always accompanied by music accompaniment (gondang), dance (tor-tor), prayers and offerings. It was delivered by a leader called "King Marnangkok Naipospos". The music used by parmalim is a gondang kesapi. The Pahasada ritual performed by parmalim believers is always accompanied by the gondang kesapi played by the parmalim community itself. How the gondang form and its function in the Si Pahasada ritual of the Parmalian people became an interesting study to be carried out. Whether the gourd haspi has a special meaning in this ritual, how its existence and what its function for the parmalim community groups will be discussed in concrete in this study.

\section{Methodology}

Study on Gondang Hasapi at Parmalim Si Pahasada Ritual Ceremony, conducted by qualitative method. Qualitative studies typically compose field data either verbal or written utensils and other sources such as images, numbers, art performances, reliefs, and other forms of data that are usually transposed as texts, and the data is usually derived from the results surveys, observations, interviews, documents, recordings, evaluation results and so on ". To analyze the data, all forms of data collected through interviews, observations, and literature studies, and audio visual recordings were subsequently processed and analyzed carefully. The processed and analyzed results are interpreted based on the results of processing and data analysis, then systematically arranged with qualitative descriptive techniques for describing the problem being studied using the description and not in the form of numbers.

\section{Discussion}

\subsection{The existence of The Shapes of Gondang Hasapi in Sipaha Sada ritual}

Pahasada is one of the rituals in Malim's use of the Batak Toba community in Highland North Sumatra. This ceremony is special to commemorate the day of birth or they call it "hatumanubu". According to the traditions of Paralim people this activity is usually concentrated in a place called "Bale Partonggoan Huta Tinggi" and accompanied by traditional music that is gondang kesapi. Its musical instruments ensemble used by the Parmalim community consists of Hasapi ende, Hasapi doal, Garantung, Sarune etek and Hesek. Before I explained how the form of gondang is involved in this ritual it is better to show first how the process of ritual implementation "Si pah sada"

The ritual process of Si Pahasada (day of birth) is done for two days, this can be explained as follows:

\section{- First day}

Before the implementation of Si Pahasada ceremony began, the officers (parhobas) first prepared everything needed for the ceremony. The community gathered at "Huta Tinggi marhobas" (working) preparing all the preparations for ceremony. The people who work in the fields of ceremonial needs include women and men. Women served as food cookers for all participants and included dishes for offerings to god, consisting of one goat, a chicken and several other ingredients with the help of some men. For other men prepares a place of 
worship and musical instrument that will be used, among others consists of instruments of silence (harpoon), sarune (serunai), hesek and garantung. All the above mentioned materials and equipment should be included in the presentation room (Bale Pasogit Partonggoan).

After the preparation of the place and the offers have finished and It was done sanitizing with the water of the poison (water purification). Done by splashing the three cleansing water to the left and right side of the offerings, When the preparation stage of the offerings has been completed then all participants who have been outside can enter into the room called "Bale Pasogit Partonggoan" and sit in order. One of the leaders of the ceremony called "ulupunguan" signaled from below that the ceremony could be started.

As the beginning of the ceremony was marked by splashing the second floor of the pangurason (sanitation) from the second floor to all the participants on the ground floor before asking the pargonsi (music player) to ring the music three times each directed to King Nasiakbagi, King Na Opat Pulu Four, and to Debata Mulajadi Nabolon. Afterwards it was recited a prayer related to the ceremony of Si Pahasada which is essentially to commemorate the birth day as well as to seek protection according to the nature possessed.

With the completion of pronunciation of prayers, then a special ceremonial ceremony was performed by a slaughterhouse. Afterwards the leader of the ceremony asked to pargonsi (music player) to sound some kind of gondang. The first gondang is the opening drum that is directed to King Nasiakbagi, while the second drum is a special gondang which commemorates the birth of Simarimbulubosi called gondang pangharoan

\section{- Second Day}

The second day of Si Pahasada ceremony was almost the same as the first day of the ceremony which started after lunch. The only difference is the content of prayers. If the first day is to commemorate the birth of Simarimbulubosi and to present the sacraments, then on the second day the contents of the prayers are focused on the thanksgiving and apply to Debate (God) to be given a hagabeon, safety (hahorason), physical and spiritual strength (hagogoon). These three petitions are submitted because they believe the power of Debata (God) to mankind. In this case there are also some gondang as cover.

\subsection{The shapes of gondang in ritual Si pahasada}

There are several kinds of drums that are special to commemorate the birth of Simarimbulubosi. Here are the names of the drum in question:

a. Gondang Inanta of Tuhan Simarimbulubosi for the mother who gave birth to Simarimbulubosi for his services and sacrifices. Through him was born a person who brought goodness to mankind (parmalim). This gondang is the gondang gondang of the twelve gondang that exist. The process of the birth of Simarimbulubosi which is the incarnation of the god Debata Mulajadi Na Bolon,

b. Gondang hatutubu by Tuhan Simarimbulubosi (gondang saat lahir), yaitu gendang yang berarti mengenang dan memperingati saat-saat kelahiran Simarimbulubosi. Debata Mulajadi Na Bolon with His love sent Simarimbulubosi to convey His teachings for the salvation of men,

c. The goddess of Tuhan Simarimbulubosi (drumming the birth of her birth) is a drum that means remembering and commemorating the times of the community at that time welcomed the birth of Simarimbulubosi. Gondang sounded to welcome the birth of Simarimbulubosi, as well as the expression of the joy of the parmalim of 
the people in welcoming the birth of their Lord to the earth,

d. Gondang is made by Tuhan Simarimbulubosi (drumming drum) which is a drum that means to remember and to commemorate the "boru in Debata" (Debata's daughter) boasting Simarimbulubosi after birth from his mother's womb. This gondang tells Mother's love for her child on a stillborn baby, in her mother's arms. Gondang is also an expression of the age of Simarimbulubosi which is always protected by Debata Mulajadi Na Bolon,

e. Gondang is tempted by Tuhan Simarimbulubosi (his childhood drum), remembering and celebrating Simarimbulubosi's childhood and youth. Gondang tells the story of the time when Simarimbulubosi turns to teenagers or adults and works to spread the teachings, teachings, and laws of God to humans, which is to say about the teachings of Hamalimon. This gondang also contains the story of how Simarimbulubosi had been tempted to teach and exercise his beliefs, namely the insults of those who had escaped the teachings of God. The embodiment of a purely and pure, pure and holy mind of the Simarimbulubosi youth (marroha hamalimon), well-behaved and sacred (marpangalaho hamalimon), and having a sacred and spiritual body (mardaging dohot martondi hamalimon) is described by this gondang

f. Gondang ulaon ni Tuhan Simarimbulubosi (the prophetic drum)which is a drum which means to remember and to commemorate when Simarimbulubosi performed the task of conveying the teachings to his people. This Gondang narrates and describes Simarimbulubosi's time in teaching and fulfilling his religious duties,

g. Gondang habengeton of God Simarimbulubosi (persistence drum)is a gondang which means to remember and to commemorate his determination in leading and protecting his people during his time in this world (banua tonga). Gondang describes Simarimbulubosi's suffering in discharging his duties. The suffering he never paid back to the people who did not like it. Gondang implies how the test of patience from the life experienced by Simarimbulubosi in teaching the command of Mulajadi Na Bolon,

h. Gondang panghonghopan ni Tuhan Simarimbulubosi (defense drum) which is a gondang which means to remember and to commemorate his affliction during the lead and protection of his people. This gondang illustrates how Simarimbulubosi still protects humans, albeit with the obstacles of the people around them. The infinite affection (parvong roha, parroha simulak-ulak) from Simarimbulubosi fruites the hope of Mulajadi $\mathrm{Na}$ Bolon so that man will be kept (doppelk) and preserved not to fall into sin,

i. Gondang hasiakbagion ni Tuhan Simarimbulubosi (drums of misery), which is gondang which means to remember and to commemorate his suffering during his leadership and helping his people.Gondang describes how Simarimbulubosi suffers because he wants to fight for his people. He urged his people to feel the vitality and meaning of the bitterness of life. Because bitterness is the way to go and achieve eternal glory,

j. Gondang hamonangan ni Tuhan Simarimbulubosi (drum victory) namely gondang which means to remember and to commemorate victory when dealing with the devil.This gondang describes Simarimbulubosi's excitement when it wins the demons (sibolis) as an evil force. After that he departed and returned to Mulajadi $\mathrm{Na}$ Bolon the Creator who sent and sent him,

k. Gondang pangolop-olopan ni Tuhan Simarimbulubosi (drums celebrate its excitement) is 
a gondang which means remembering and commemorating the moments of his excitement after winning against the devil. Gondang describes the joy of every people who also feel the bitterness of Simarimbulubosi. Bitterness is a guide to life in the Word of God, the law of God in the valley,

1. Gondang sitio-tio of God Simarimbulubosi (the destination drum, receiver and intermediary), which is meaningful as a statement that Simarimbulubosi is an intermediary, receiver or liaison between man and Debata, especially in the case of prayer and all the deeds of worship during mankind this world. This gondang illustrates the triumph of the faith of the ummah and the hope of the Mulajadi Na Bolon or the constant blessings of Him and the fortune of a life of adequate.

All the names of the gondangs mentioned above, must be presented at every ceremony of Si Pahasada. The sound of each drum is standard and can not be changed at any time. Every gondang is played, it must be accompanied by a tortor (dance), but that can be dancing is self-propelled, while other participants can only be in a sitting position of worship. With the completion of the whole gondang was played, then the core ceremony of Si Pahasada on the first day.

\subsection{Gondang Hasapi Function At Ritual Ceremony of Parmalim Si Pahasada}

At the ritual ceremony of parmalim Si Pahasada, gondang hasapi has a very important role, because through the sounds of gondang this is all praise and petition of parmalim society can reach Debata Mulajadi Nabolon (God Almighty ). To discuss the function of gondang music at the ritual ceremony of Si Pahasada, through interviews with the writer's community see eight functions available at the ritual ceremony of Si Pahasada. The eight functions are as follows:

a. Aesthetic Function Function.

There is a feature of the gondang aesthetic function for Huta Tinggi parmalim community at penganali ritual Si Pahasada, where the parmalim community enjoys the harmony and beauty of gondang music that can make the parmalim community express in manortor (dancing).

b. Function.

With god In Si Pahasada ceremony, before asking for the gondang always preceded by prayer. They believe that the prayer they convey will come through the sounds of the gondang. The use of gondang in this ceremony is the vertical communication between human beings and their God, where the parmalim community expresses gratitude, requests and forgiveness to Ompung Mulajadi Nabolon in the form of prayer and will come through the media, the sound of the gondang kesapi.

c. Symbolic Functions.

In Pahasada parmalim ceremony performed by Huta Tinggi parmalim community, gondang kesapi is a symbol of each different gondang presentation. Each gondang has a good distinction in sounds and gondang names and symbolizes a life event.

d. Physical response function.

The physical response function is seen from the Si Pahasada ceremony, where they hear the sounds of emotional melodies, spontaneously they physically act as their physical proof of evidence by listening to music to start dancing or merging 
simultaneously, lifting and lowering the hands and other parts of the music gondang.

e. Function Enforcing Compatibility with Social Norms.

Gondang hasapi very clearly in accordance with social norms, where gondang kesapi is played by musicians who also come from the community of parmalim to defend the value of culture and social norms in the community of parmalim.

f. Functions of the Institution of Social and Religious Rituals.

In the Si Pahasada ceremony performed by the Huta Tinggi parmalim community, the gondang experience is a means of verification of the prayer they convey, this can be seen from its function before and after prayer is always accompanied by gondang music as a sign of confirmation for prayers submitted to God.

g. Function Contribution to Sustainability and Cultural Stability.

Gondang music has contributed to the cultural stability and contribution of the parmalim community which always demonstrates the sustainability and stability of the gondang culture in its religious rituals, and also stabilizes the culture through rituals to other members of the community and even teaching young children to continue to preserve this culture.

h. Contributing Functions to Community Integration.

Gondang members of the community can be integrated together and run their ritual beliefs together. They gather to work together to engage and trust the gondang as the bridge of their prayers all that their god will accept. In addition, they go through their gondang together and remind each other of their unity in carrying out this ritual.

\section{Conclusion}

Based on the findings in this study, it can be concluded that some of these are:

1. There are 12 presentation reports of the gondang ensembles presented during this ritual, the reportoar is: a) Gondang Inanta ni Tuhan Simarimbulubosi (biggner drum), b) Gondang hatutubu ni Tuhan Simarimbulubosi (Drum at birth), c) Gondang parharoanan ni Tuhan Simarimbulubosi (his birth welder drum), d) Gondang didang-didang ni Tuhan Simarimbulubosi (menimang-nimang drums), e) Gondang haposoon ni Tuhan Simarimbulubosi (his youth drum), f) Gondang ulaon ni Tuhan Simarimbulubosi (his prophetic drum) ) Gondang habengeton of God Simarimbulubosi (drums of fortitude), h) Gondang taing ni Gusti Simarimbulubosi (drums of its brevity), i) Gondang hasiakbagion ni Tuhan Simarimbulubosi (drums of suffering), j Gondang hamonangan ni Tuhan Simarimbulubosi (drums of victory), k) Gondang Lord Simarimbulubosi (drums celebrate his joy), 1) Gondang sitio-tio of Lord Simarimbulubosi (drums destination, recipient and intermediary).

2. In this study also found eight functions of gondang in the ritual of Parmalim $\mathrm{Si}$ Pahasada, namely: a) Aesthetic function, b) communication function, c) Symbolic function, d) Physical response function, e) Enforcement of social norms, Social institution validation. g) religious ritual function, h) cultural continuity and stability, i) contribution to community integration. 


\section{References}

Bungin, Burhan. 2011. Penelitian Kualitatif. Jakarta: Kencana.

Djelantik, AAM. 1990. Pengantar Pasar Estetika. Denpasar: STSI Denpasar . 1999. Estetika. Bandung: Masyarakat Seni Pertunjukan Indonesia.

Gultom, Ibrahim. 2010. Agama Malim di Tanah Batak. Jakarta: Bumi Aksara.

Gultom, Iven Sius Deo. 2010. Masuk dan Berkembangnya Agama Malim di Kota Medan

Hadi, Y. Sumandiyo.2000. Seni Dalam Ritual Agama. Yokyakarta: Yayasan untuk Indonesia.

Langer, Susanne K. 1998. Rout-Ledge Encyclopedia Of Philosophy. London Merriam, Alan P. 1964. The Anthopology Of Music. Evanston Illinois: North Western University Press.

Nadapdap, Tetty Irawati. 2009. Konstruksi Upacara Si Pahalima dalam Kepercayaan Parmalim.

Nainggolan Irvan Parhusip, 2019, Bentuk Penyajian Gondang HahomionPada Upacara Ritual Horjabius Desa Tomok Kecamatan Simanindo Kabupaten Samosir, thesis of Faculty of Art and Language in State university of Medan.

Pasaribu, Ben M. 2004. Musikalitas+Etnisitas=Pluralitas Dalam Musik Etnik. Medan: Pusat Dokumentasi Kebudayaan Batak HKBP Nomensen.

Rafael, Benny. 2010. Studi Deskriptif Tentang Strategi Adaptasi Penganut Ugamo Malim di Kota Medan.

Rusadi, Eko. 2004. Ugasan Torop dalam Ugamo Malim.

Situmorang, Jaulahan. 1992. Penuntun Adat Praktis. Pematang Siantar. Soedarsono. 1990. Tinjauan Seni Sebuah Pengantar untuk Apresiasi Seni. Yokyakarta: Saku Dayar Sana. 1999. Seni Pertunjukan Indonesia di Era Globalisasi. Jakarta: Direktorat Jenderal Pendidikan Tinggi Departemen Pendidikan dan Kebudayaan.

Tambunan, H. Emil. 1982. Sekelumit Mengenai Masyarakat Batak Toba dan Kebudayaannya. Bandung: Tarsito. 